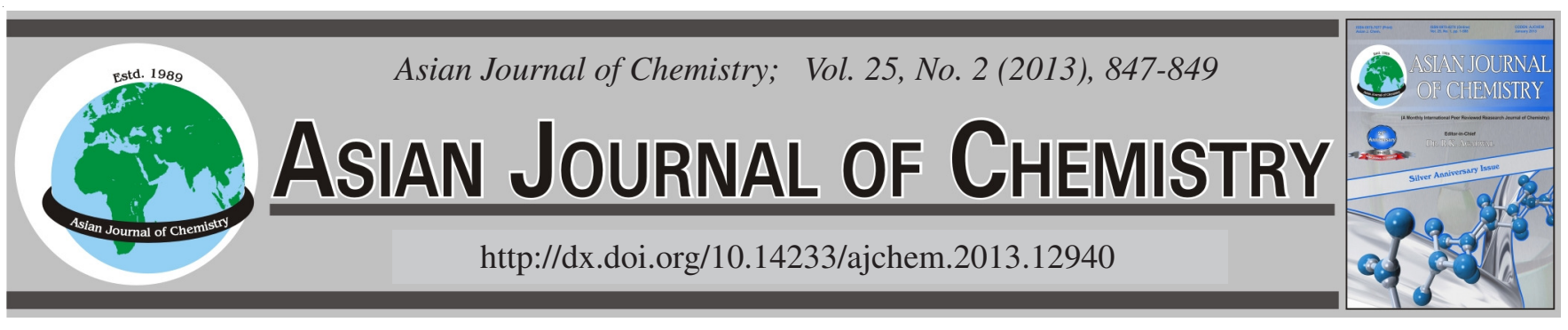

\title{
Synthesis and Crystallographic Study of Cobalt Complex Derived from 5-Chloro-salicylaldehyde and Cyclohexanamine
}

\section{SUO-JIAN LAN}

Department of Chemistry and Chemical Engineering, Baoji University of Arts and Sciences, Baoji 721007, P.R. China

Corresponding author: E-mail: suojianlan@163.com

The coblat complex with molecular formula $\left[\mathrm{C}_{26} \mathrm{H}_{30} \mathrm{Cl}_{2} \mathrm{CoN}_{2} \mathrm{O}_{2}, \mathrm{Mr}=532.35\right]$ has been synthesized and characterized by elemental analysis and $\mathrm{X}$-ray diffraction. As expected, the molecular structure adopts a trans configuration about the $\mathrm{C}=\mathrm{N}$ double bond. It crystallizes in monoclinic system, space group Pbca with $a=14.875(3) \AA, b=13.569(2) \AA, c=24.957(5) \AA, \beta=90^{\circ}, V=5037.6(14) \AA^{3}, Z=8, D c$ $=1.404 \mathrm{Mg} / \mathrm{m}^{3}, \mathrm{~F}_{(000)}=2216, \mu\left(\mathrm{MoK}_{\alpha}\right)=0.919 \mathrm{~m} \mathrm{~m}^{-1}, \mathrm{R}=0.0415$ and $\mathrm{wR}=0.0492$ of the 5667 collection, 4690 were unique. The title compound, $\left[\mathrm{C}_{26} \mathrm{H}_{30} \mathrm{Cl}_{2} \mathrm{~N}_{2} \mathrm{O}_{2}\right]$ is a mononuclear cobalt(II) complex. The Co atom is four-coordinated by two $\mathrm{N}$ atoms and two $\mathrm{O}$ atoms from two Schiff base ligands in a slightly distorted tetrahedral geometry.

Key Words: Bis[4-chloro-2-(cyclohexyliminomethyl)phenolato]cobalt(II), Crystal structure, Cobalt compound.

\section{INTRODUCTION}

Cobalt complexes are of great interest in coordination chemistry in relation to catalysis, enzymatic reactions, magnetism and molecular architecture ${ }^{1-3}$. As an extension of work on the structural characterization of cobalt compound, the crystal structure of a newly synthesized compound(I) is reported here.

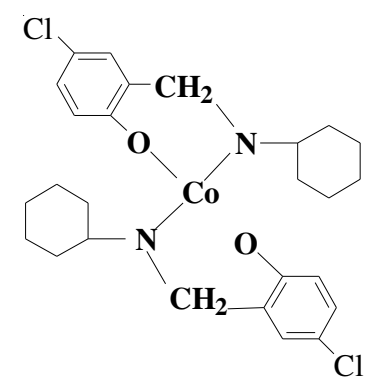

Compared the new synthesized compound with two cobalt(II) compounds reported previously ${ }^{4}$.

\section{EXPERIMENTAL}

Cyclohexanamine used in the experiment is of analytical purity and 5-chlorosalicylaldehyde is a biochemical reagent.

Preparation of the crystal: 5-Chlorosalicylaldehyde (0.1 mmol, $15.7 \mathrm{mg}), \mathrm{CoCl}_{2} \cdot 6 \mathrm{H}_{2} \mathrm{O}(0.1 \mathrm{mmol}, 24.2 \mathrm{mg})$ and cyclohexanamine $(0.1 \mathrm{mmol}, 9.3 \mathrm{mg})$ were dissolved in methanol $(10 \mathrm{~mL})$. The mixture was stirred for $0.5 \mathrm{~h}$ at room temperature to give a clear brown solution. After keeping the resulting solution in air for $11 \mathrm{~d}$, brown block-shaped crystals of (I) were formed on slow evaporation of the solvent. The crystals were collected, washed with methanol and dried in a vacuum desiccator using anhydrous $\mathrm{CaCl}_{2}$ (yield $54 \%$ ). The reaction mechanism is shown in Fig. 1. Analysis found: $\mathrm{C}$ 58.64, H 5.63\%; calculated for: $\left[\mathrm{C}_{26} \mathrm{H}_{30} \mathrm{Cl}_{2} \mathrm{CoN}_{2} \mathrm{O}_{2}\right] \mathrm{C} 58.64$, H $5.64 \%$.

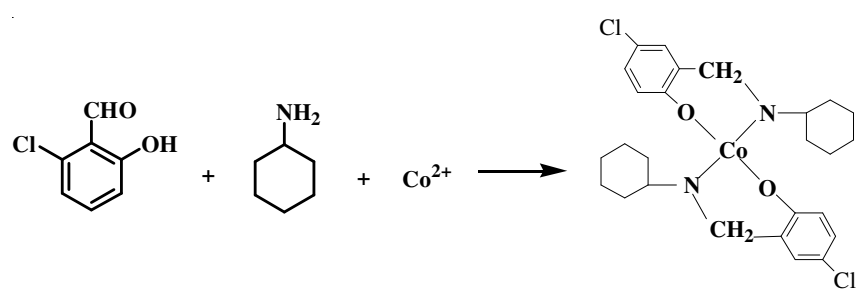

Fig. 1. Scheme of the chemical reaction

Crystal structure determination and refinement: Solvent loss technique has been employed for the growth of yellow rod-shaped crystals of the title compound. A crystal having good morphology $(0.48 \mathrm{~mm} \times 0.48 \mathrm{~mm} \times 0.12 \mathrm{~mm})$ was chosen for three-dimensional intensity data collection using a SMART diffractometer. $\mathrm{MoK}_{\alpha}$ radiation $(\lambda=0.71073 \AA)$ was used for the data collection. A total of 5667 reflections were recorded and out of this number 4690 reflections $(0 \leq \mathrm{h} \leq 18,0 \leq \mathrm{k} \leq$ $16,-30 \leq 1 \leq 1$ ) were treated as observed. The structure has been solved with SHELXS-97 and full-matrix least-squares 
refinement has been carried out using SHELXTL-97 software. The final refinement cycle converged $\mathrm{R}=0.0415$ and $\mathrm{wR}=$ 0.0492. The maximum shift to esd. ratio for all atoms in the final cycle is 0.001 . Final cycle of refinement results the residual electron density in the range from -0.252 to $0.353 \mathrm{e} / \AA^{3}$. The crystallographic data are summarized in Table-1.

\section{TABLE-1}

CRYSTAL DATA AND OTHER EXPERIMENTAL DETAILS

\begin{tabular}{|c|c|}
\hline No. & y2041 \\
\hline Crystal description & Yellow rod \\
\hline Chemical formula & $\mathrm{C}_{26} \mathrm{H}_{30} \mathrm{Cl}_{2} \mathrm{CoN}_{2} \mathrm{O}_{2}$ \\
\hline Molecular weight & 532.35 \\
\hline Cell parameters & $\begin{array}{c}\mathrm{a}=14.875(3) \AA \\
\mathrm{b}=13.569(2) \AA \\
\mathrm{c}=24.957(5) \AA \\
\beta=90^{\circ}\end{array}$ \\
\hline Unit cell volume & $5037.6(14) \AA 3$ \\
\hline Crystal system & Orthorhombic \\
\hline Space group & Pbca \\
\hline Density (calculated) & $1.404 \mathrm{mg} / \mathrm{m}^{3}$ \\
\hline No. of molecules per unit cell Z & 8 \\
\hline Absorption coefficient (?) & $0.9195 \mathrm{~m} \mathrm{~m}^{-1}$ \\
\hline Absorption correction & psi-scan \\
\hline Max. and min. transmission & 0.9997 and 0.8955 \\
\hline $\mathrm{F}_{(000)}$ & 2216 \\
\hline Crystal size & $0.48 \mathrm{~mm} \times 0.48 \mathrm{~mm} \times 0.12 \mathrm{~mm}$ \\
\hline Completeness to theta $=25.02$ & $99.5 \%$ \\
\hline$\theta$ range for entire data collection & $1.63<\theta<25.50^{\circ}$ \\
\hline Reflections collected & 5667 \\
\hline Independent reflections & $4690\left[R_{\text {(int) }}=0.0245\right]$ \\
\hline Observed reflections & 2154 \\
\hline Refinement method & Full-matrix least-squares on $\mathrm{F}_{2}$ \\
\hline Data/restraints/parameters & $4690 / 0 / 299$ \\
\hline Limiting indices & $0 \Leftarrow \mathrm{h} \Leftarrow 18,0 \Leftarrow \mathrm{k} \Leftarrow 16,-30 \Leftarrow \mathrm{l} \Leftarrow 1$ \\
\hline Final R-factor & 0.0415 \\
\hline WR & 0.0492 \\
\hline Weight & $\begin{array}{c}\mathrm{w}=1 /\left[\sigma^{2}(\mathrm{Fo})^{2}+(0.0100 \mathrm{P})^{2}+\right. \\
0.0000 \mathrm{P}] \text { where } \mathrm{P}=\left(\mathrm{Fo}^{2}+2 \mathrm{Fc}^{2}\right) / 3\end{array}$ \\
\hline Goodness-of-fit on $\mathrm{F}_{2}$ & 0.837 \\
\hline Final residual electron density & $-0.252<\rho<0.353$ e $\AA-3$ \\
\hline$(\Delta / \sigma) \max$ in the final cycle & 0.001 \\
\hline
\end{tabular}

\section{RESULTS AND DISCUSSION}

Selected bond distances and bond angles are listed in Table-2. Selected torsion angles are given in Table-3. An ORTEP view of the molecule with the atomic numbering scheme (the structure of (I), showing $30 \%$ probability displacement ellipsoids and the atom-numbering) is shown in Fig. 2. The geometry of the molecule has been calculated using the software. From the results, it is known that all the bond lengths and angles are in normal ranges comparable to those observed in a similar antipyrine Schiff base (Table-4).

Compared the newly synthesized cobalt(II) compounds with the other two (the structures are shown in Figs. 4 and 5), it was found that compound structures obtained are different in the three cobalt systems. When $\mathrm{Co}\left(\mathrm{NO}_{3}\right)_{2} \cdot 6 \mathrm{H}_{2} \mathrm{O}$ or $\mathrm{CoCl}_{2} \cdot 6 \mathrm{H}_{2} \mathrm{O}$ was used, the structures of the synthesized cobalt(II) compounds are almost the same.

$\mathrm{Co}\left(\mathrm{CH}_{3} \mathrm{COOH}\right)_{2} \cdot \mathbf{4} \mathbf{H}_{2} \mathrm{O}$ system: 5 -Chlorosalicylaldehyde $(0.1 \mathrm{mmol}, 15.7 \mathrm{mg})$ and cobalt(II) acetate tetrahydrate $(0.1$ mmol, $24.9 \mathrm{mg})$ and cyclohexanamine $(0.1 \mathrm{mmol}, 9.3 \mathrm{mg})$ were dissolved in methanol $(10 \mathrm{~mL})$. The mixture was stirred
TABLE-2

SELECTED BOND LENGTHS $(\AA)$ AND BOND ANGLES $\left({ }^{\circ}\right)$

\begin{tabular}{cccc}
\hline Bond & Dist $(\AA)$ & Angle & $\left({ }^{\circ}\right)$ \\
\hline $\mathrm{Co}-\mathrm{O}(2)$ & $1.912(2)$ & $\mathrm{O}(2)-\mathrm{Co}-\mathrm{O}(1)$ & $121.06(9)$ \\
$\mathrm{Co}-\mathrm{O}(1)$ & $1.916(2)$ & $\mathrm{O}(2)-\mathrm{Co}-\mathrm{N}(2)$ & $94.93(10)$ \\
$\mathrm{Co}-\mathrm{N}(2)$ & $1.994(2)$ & $\mathrm{O}(1)-\mathrm{Co}-\mathrm{N}(2)$ & $112.86(10)$ \\
$\mathrm{Co}-\mathrm{N}(1)$ & $1.998(2)$ & $\mathrm{O}(2)-\mathrm{Co}-\mathrm{N}(1)$ & $112.82(10)$ \\
$\mathrm{N}(2)-\mathrm{C}(7)$ & $1.283(3)$ & $\mathrm{O}(1)-\mathrm{Co}-\mathrm{N}(1)$ & $94.45(10)$ \\
$\mathrm{N}(1)-\mathrm{C}(20)$ & $1.281(3)$ & $\mathrm{N}(2)-\mathrm{Co}-\mathrm{N}(1)$ & $122.94(10)$ \\
$\mathrm{N}(2)-\mathrm{C}(8)$ & $1.486(3)$ & $\mathrm{C}(14)-\mathrm{O}(1)-\mathrm{Co}$ & $123.4(2)$ \\
$\mathrm{O}(1)-\mathrm{C}(14)$ & $1.315(3)$ & $\mathrm{C}(1)-\mathrm{O}(2)-\mathrm{Co}$ & $125.6(2)$ \\
$\mathrm{O}(2)-\mathrm{C}(1)$ & $1.298(3)$ & $\mathrm{C}(20)-\mathrm{N}(1)-\mathrm{C}(21)$ & $117.4(3)$ \\
$\mathrm{C}(1)-\mathrm{C}(2)$ & $1.415(4)$ & $\mathrm{C}(20)-\mathrm{N}(1)-\mathrm{Co}$ & $122.0(2)$ \\
$\mathrm{C}(2)-\mathrm{C}(3)$ & $1.363(4)$ & $\mathrm{C}(21)-\mathrm{N}(1)-\mathrm{Co}$ & $120.6(2)$ \\
$\mathrm{C}(3)-\mathrm{C}(4)$ & $1.387(4)$ & $\mathrm{C}(7)-\mathrm{N}(2)-\mathrm{C}(8)$ & $116.5(3)$ \\
$\mathrm{C}(2)-\mathrm{H}(2)$ & 0.9300 & $\mathrm{C}(7)-\mathrm{N}(2)-\mathrm{Co}$ & $122.0(2)$ \\
$\mathrm{C}(3)-\mathrm{H}(3)$ & 0.9300 & $\mathrm{C}(8)-\mathrm{N}(2)-\mathrm{Co}$ & $121.5(2)$ \\
$\mathrm{C}(12)-\mathrm{H}(12 \mathrm{~A})$ & 0.9700 & $\mathrm{O}(2)-\mathrm{C}(1)-\mathrm{C}(2)$ & $119.3(3)$ \\
\hline
\end{tabular}

\begin{tabular}{|c|c|}
\hline \multicolumn{2}{|c|}{$\begin{array}{c}\text { TABLE-3 } \\
\text { SELECTED TORSION ANGLES }\left(^{\circ}\right) \\
\text { FOR NON-HYDROGEN ATOMS }\end{array}$} \\
\hline $\mathrm{O}_{2} \mathrm{CoO}_{1} \mathrm{C}_{14} 144.7(2)$ & $\mathrm{N}_{2} \mathrm{CoO}_{1} \mathrm{C}_{14}-104.0(2)$ \\
\hline $\mathrm{N}_{1} \mathrm{CoO}_{1} \mathrm{C}_{14} 24.6(2)$ & $\mathrm{O}_{1} \mathrm{CoO}_{2} \mathrm{C}_{1} 136.3(2)$ \\
\hline $\mathrm{N}_{2} \mathrm{CoO}_{2} \mathrm{C}_{1} 15.8(3)$ & $\mathrm{N}_{1} \mathrm{CoO}_{2} \mathrm{C}_{1}-113.2(3)$ \\
\hline $\mathrm{O}_{2} \mathrm{CoN}_{1} \mathrm{C}_{20}-141.8(2)$ & $\mathrm{O}_{1} \mathrm{CoN}_{1} \mathrm{C}_{20}-15.4(2)$ \\
\hline $\mathrm{N}_{2} \mathrm{CoN}_{1} \mathrm{C}_{20} 105.6(2)$ & $\mathrm{O}_{2} \mathrm{CoN}_{1} \mathrm{C}_{21} 36.2(2)$ \\
\hline $\mathrm{O}_{1} \mathrm{CoN}_{1} \mathrm{C}_{21} 162.7(2)$ & $\mathrm{N}_{2} \mathrm{CoN}_{1} \mathrm{C}_{21}-76.3(2)$ \\
\hline $\mathrm{O}_{2} \mathrm{CoN}_{2} \mathrm{C}_{7}-8.7(3)$ & $\mathrm{O}_{1} \mathrm{CoN}_{2} \mathrm{C}_{7}-135.4(2)$ \\
\hline $\mathrm{N}_{1} \mathrm{CoN}_{2} \mathrm{C}_{7} 112.6(2)$ & $\mathrm{O}_{2} \mathrm{CoN}_{2} \mathrm{C}_{8} 168.5(2)$ \\
\hline $\mathrm{O}_{1} \mathrm{CoN}_{2} \mathrm{C}_{8} 41.8(2)$ & $\mathrm{N}_{1} \mathrm{CoN}_{2} \mathrm{C}_{8}-70.1(2)$ \\
\hline $\mathrm{CoO}_{2} \mathrm{C}_{1} \mathrm{C}_{2} 166.4(2)$ & $\mathrm{CoO}_{2} \mathrm{C}_{1} \mathrm{C}_{6}-14.0(5)$ \\
\hline
\end{tabular}

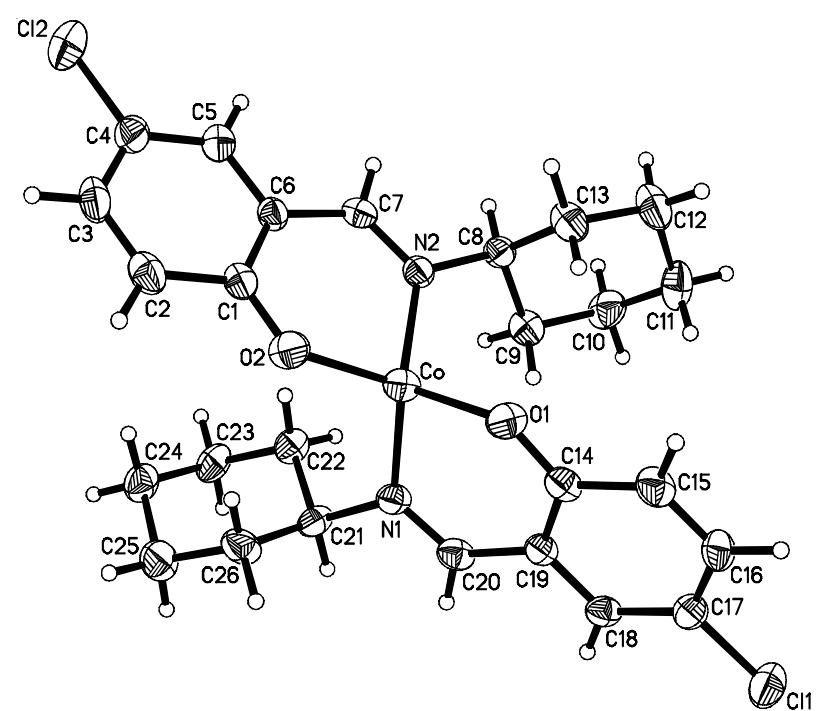

Fig. 2. The structure of (I), showing $30 \%$ probability displacement ellipsoids and the atom-numbering

for $0.5 \mathrm{~h}$ at room temperature to give a clear brown solution. After allowing the resulting solution to stand in air for $11 \mathrm{~d}$, brown block-shaped crystals were formed at the bottom of the vessel by slow evaporation of the solvent. The crystals were isolated by filtration, washed with methanol and dried in a vacuum desiccator using anhydrous $\mathrm{CaCl}_{2}$ (yield $54 \%$ ).

$\mathrm{Co}\left(\mathrm{NO}_{3}\right)_{2} \cdot \mathbf{6} \mathbf{H}_{2} \mathrm{O}$ system: 5-Chlorosalicylaldehyde $(0.1$ mmol, $15.7 \mathrm{mg}), \mathrm{Co}\left(\mathrm{NO}_{3}\right)_{2} \cdot 6 \mathrm{H}_{2} \mathrm{O}(0.1 \mathrm{mmol}, 29.1 \mathrm{mg})$ and cyclohexanamine $(0.1 \mathrm{mmol}, 9.3 \mathrm{mg})$ were dissolved in methanol $(10 \mathrm{~mL})$. The mixture was stirred for $0.5 \mathrm{~h}$ at room 


\begin{tabular}{|c|c|c|c|c|}
\hline \multicolumn{5}{|c|}{$\begin{array}{c}\text { TABLE- } 4 \\
\text { SELECTED BOND LENGTHS }(\AA) \text { AND BOND ANGLES }\left({ }^{\circ}\right) \text { OF THREE SYSTEM }\end{array}$} \\
\hline System & Bond & Dist $(\AA)$ & Angle & $\left(^{\circ}\right)$ \\
\hline \multirow{6}{*}{$\mathrm{Co}\left(\mathrm{NO}_{3}\right)_{2} \cdot 6 \mathrm{H}_{2} \mathrm{O}$} & $\mathrm{Co}-\mathrm{O}(2)$ & $1.9092(18)$ & $\mathrm{O}(2)-\mathrm{Co}-\mathrm{O}(1)$ & $121.42(8)$ \\
\hline & $\mathrm{Co}-\mathrm{O}(1)$ & $1.9149(16)$ & $\mathrm{O}(2)-\mathrm{Co}-\mathrm{N}(2)$ & $95.18(8)$ \\
\hline & $\mathrm{Co}-\mathrm{N}(2)$ & $1.997(2)$ & $\mathrm{O}(1)-\mathrm{Co}-\mathrm{N}(2)$ & $112.63(8)$ \\
\hline & $\mathrm{Co}-\mathrm{N}(1)$ & $2.0055(19)$ & $\mathrm{O}(2)-\mathrm{Co}-\mathrm{N}(1)$ & $112.57(8)$ \\
\hline & $\mathrm{O}(1)-\mathrm{C}(1)$ & $1.314(3)$ & $\mathrm{O}(1)-\mathrm{Co}-\mathrm{N}(1)$ & $94.41(8)$ \\
\hline & $\mathrm{O}(2)-\mathrm{C}(14)$ & $1.300(3)$ & $\mathrm{N}(2)-\mathrm{Co}-\mathrm{N}(1)$ & $122.87(8)$ \\
\hline \multirow{6}{*}{$\mathrm{Co}(\mathrm{OAc})_{2} \cdot 4 \mathrm{H}_{2} \mathrm{O}$} & $\mathrm{Co}-\mathrm{O}(1)$ & $2.0251(18)$ & $\mathrm{O}(1)-\mathrm{Co}-\mathrm{O}(2)$ & $91.16(8)$ \\
\hline & $\mathrm{Co}-\mathrm{O}(2)$ & $2.072(3)$ & $\mathrm{O}(1)-\mathrm{Co}-\mathrm{O}(3)$ & $176.36(6)$ \\
\hline & $\mathrm{Co}-\mathrm{O}(3)$ & $2.0265(18)$ & $\mathrm{O}(1)-\mathrm{Co}-\mathrm{O}(4)$ & $89.13(9)$ \\
\hline & $\mathrm{Co}-\mathrm{O}(4)$ & $2.072(3)$ & $\mathrm{O}(1)-\mathrm{Co}-\mathrm{O}(5)$ & $89.21(8)$ \\
\hline & $\mathrm{Co}-\mathrm{O}(5)$ & $2.114(2)$ & $\mathrm{O}(1)-\mathrm{Co}-\mathrm{O}(6)$ & $90.67(8)$ \\
\hline & $\mathrm{Co}-\mathrm{O}(6)$ & $2.057(2)$ & $\mathrm{O}(2)-\mathrm{Co}-\mathrm{O}(3)$ & $88.87(8)$ \\
\hline \multirow{6}{*}{$\mathrm{CoCl}_{2} \cdot 6 \mathrm{H}_{2} \mathrm{O}$} & $\mathrm{Co}-\mathrm{O}(2)$ & $1.912(2)$ & $\mathrm{O}(2)-\mathrm{Co}-\mathrm{O}(1)$ & $121.06(9)$ \\
\hline & $\mathrm{Co}-\mathrm{O}(1)$ & $1.916(2)$ & $\mathrm{O}(2)-\mathrm{Co}-\mathrm{N}(2)$ & $94.93(10)$ \\
\hline & $\mathrm{Co}-\mathrm{N}(2)$ & $1.994(2)$ & $\mathrm{O}(1)-\mathrm{Co}-\mathrm{N}(2)$ & $112.86(10)$ \\
\hline & Co-N(1) & $1.998(2)$ & $\mathrm{O}(2)-\mathrm{Co}-\mathrm{N}(1)$ & $112.82(10)$ \\
\hline & $\mathrm{O}(1)-\mathrm{C}(14)$ & $1.315(3)$ & $\mathrm{O}(1)-\mathrm{Co}-\mathrm{N}(1)$ & $94.45(10)$ \\
\hline & $\mathrm{O}(2)-\mathrm{C}(1)$ & $1.298(3)$ & $\mathrm{N}(2)-\mathrm{Co}-\mathrm{N}(1)$ & $122.94(10)$ \\
\hline
\end{tabular}

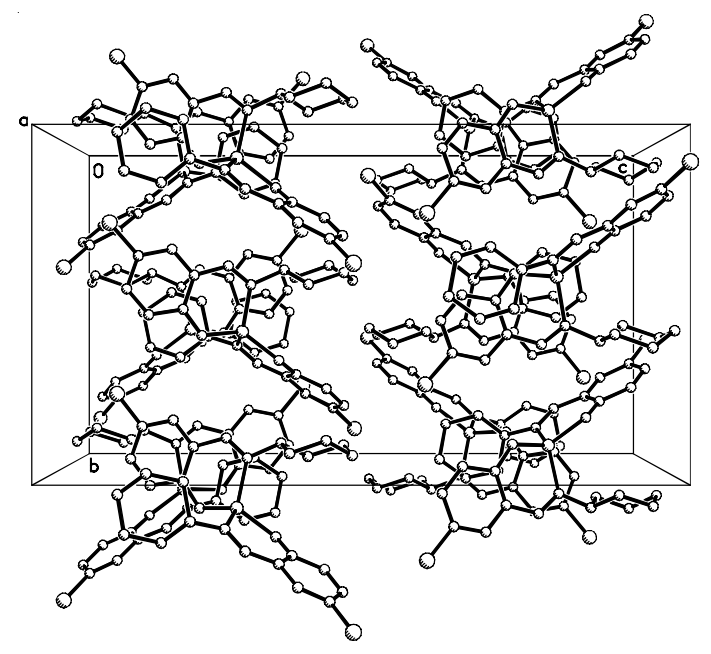

Fig. 3. Packing diagram viewed down the b-axis

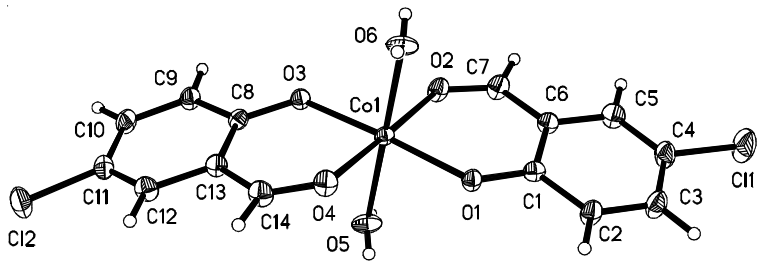

Fig. 4. Crystal structure of $\mathrm{Co}\left(\mathrm{CH}_{3} \mathrm{COOH}\right)_{2} \cdot 4 \mathrm{H}_{2} \mathrm{O}$ system

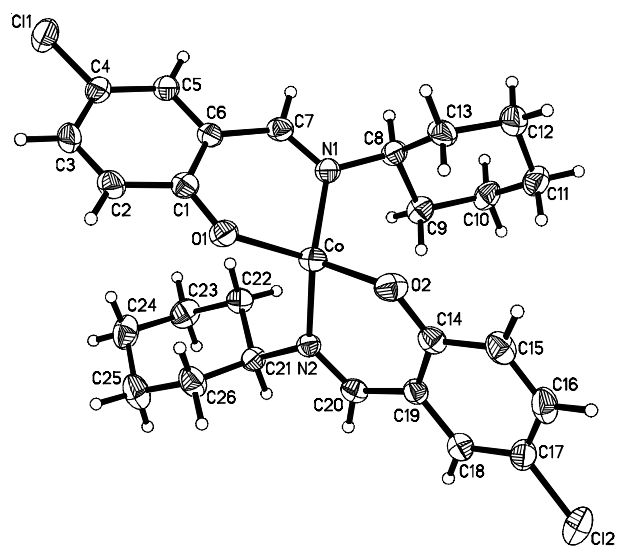

Fig. 5. Crystal structure of $\mathrm{Co}\left(\mathrm{NO}_{3}\right)_{2} \cdot 6 \mathrm{H}_{2} \mathrm{O}$ system temperature to give a clear brown solution. After keeping the resulting solution in air for $11 \mathrm{~d}$, brown block-shaped crystals of (I) were formed on slow evaporation of the solvent. The crystals were collected, washed with methanol and dried in a vacuum desiccator using anhydrous $\mathrm{CaCl}_{2}$ (yield $54 \%$ ).

\section{Conclusion}

As shown in Fig. 4, at the horizontal positions, the three trans angles at $\mathrm{Co} 1$ are all close to $180^{\circ}$. The other angles are close to $90^{\circ}$, varying from $84.79(8)-95.96(8)^{\circ}$, which indicates a slightly distorted octahedral geometry of the Co1 atom. The bond lengths around the Co1 atom are ranging from 2.025(2)2.112(2) $\AA$. The dihedral angle between the two benzene rings is $20.4(3)^{\circ}$.

Compound (I) is a mononuclear Co(II) complex. The $\mathrm{Co}$ (II) ion coordinated by two $\mathrm{O}$ and two $\mathrm{N}$ atoms from two Schiff base ligands. This $\mathrm{CoN}_{2} \mathrm{O}_{2}$ coordination forms a distorted tetrahedral geometry, with angles subtended at the $\mathrm{Co}$ (II) atom in the range 94.41(8)-122.87(8) \%. The bond lengths of Co-O range from 1.9092(18)-2.0055(19) \% A. The results were identical in both Figs. 3 and 5.

\section{ACKNOWLEDGEMENTS}

This work was supported by the Phytochemistry Key Laboratory of Shaanxi Province (No.2010JS067) and the Project of Development Programs in Science and Technology of Shaanxi Province (No. 2012JM2019).

\section{REFERENCES}

1. T.S. Billson, J.D. Crane, O.D. Fox and S.L. Heath, Inorg. Chem. Commun., 3, 718 (2000).

2. I.O. Fritsky, R. Ott, H. Pritzkow and R. Kramer, Inorg. Chim. Acta, 346, 111 (2003).

3. T. Kotera, A. Fujita, M. Mikuriya, H. Tsutsumi and M. Handa, Inorg. Chem. Commun., 6, 322 (2003).

4. Z.X. Li and X.L. Zhang, Z. Kristallogr. NCS, 220 (2005). 